\title{
Effect of Particle Immersing in Various Concentrations of Acetic Acid to Enhance the Sandwich Particleboard (SPb)
}

\section{Apri Heri Iswanto and Rehulina Mustika Melysa Togatorop}

Department of Forest Product, Faculty of Forestry, Universitas Sumatera Utara, Padang Bulan, Medan 20155, Indonesia

\section{Abstract}

Low dimensional stability and strength properties are weakness of particleboard. Particle immersing in acetic acid solution is one of treatment to improve dimensional stability of particleboard. Furthermore, the utilization of material that has good strength as surface layer will increase of strength properties of particleboard. The objective of this research was to analysis the effect of immersing particle in acetic acid solution on physical, mechanical, and durability properties of SPb made from bamboo belangke and corn stalk bagasse bonded with isocyanat. Bamboo strand and corn stalk bagasse

Corresponding Author: Apri Heri Iswanto apriheri@yahoo.com

Received: 19 February 2019 Accepted: 5 March 2019 Published: 16 April 2019

Publishing services provided by Knowledge $\mathrm{E}$

(c) Apri Heri Iswanto and Rehulina Mustika Melysa Togatorop. This article is distributed under the terms of the Creative Commons

Attribution License, which permits unrestricted use and redistribution provided that the original author and source are credited

Selection and Peer-review under the responsibility of the ICBSA Conference Committee. soaked in the acetic acid solution at various concentrations 1, 3, 5, and $7 \%(\% \mathrm{v} / \mathrm{v})$ for 24 hours. Board was produced in size of 25 by $25 \mathrm{~cm}^{2}$ with density and thickness target of $0.70 \mathrm{~g} / \mathrm{cm}^{3}$ and $1 \mathrm{~cm}$ respectively. Bamboo was place for surface layer and corn stalk bagasse as core layer with composition ratio of 1:2:1. Isocyanat resin used as binder in SPb manufacruring. Hot pressing temperature and time were set on $160^{\circ} \mathrm{C}$ and 5 minutes with pressure of $30 \mathrm{~kg} / \mathrm{cm}^{2}$. Durability testing of $\mathrm{SPb}$ using graved yard test method was conducted for 3 month. The results showed that almost all board fulfill standard excepted of internal bond value. Amount 3\% acetic acid concentration resulted best quality of board. Durability test showed that weigh loss of SPb in this research ranged of 2.45 to $6.07 \%$. It was classified into moderate to durable class.

Keywords: Sandwich particleboard, acetic acid, pre-treatment

\section{Introduction}

Sandwich particleboard $(\mathrm{SPb})$ is one of composite product that composed of strength lignocellulose materials as surface layer and lignocellulose particle as core layer. This product consisted of three layers similar with com-ply. The difference of both product was located in surface layer, com-ply using veneer or thin plywood as surface and $\mathrm{SPb}$ using other than that. The scarcity of quality wood causes the use of non-wood lignocellulosic material to substitute of wood potential to be developed.

Bamboo is one of non-wood plants that had good mechanical properties. As stated by [1] that modulus of elasticity (MoE) of bamboo around 2,600 to $8,000 \mathrm{~N} / \mathrm{mm}^{2}$. 
Furthermore, [2] and [3] reported that mechanical properties of particleboard made from bamboo bonded with urea formaldehyde (UF) resin resulted MoE of 2,000 N/mm . Bamboo is potential material to be developed to enhance strengthen of particleboard. For surface layer in particleboard, bamboo expected to improve the mechanical properties of SPb.

Similar to particleboard, SPb has a dimensional stability problem especially was using interior resin like UF resin. The utilization of exterior adhesive like isocyanat resin is one of the solutions to solve the dimensional stability problem. Another ways to improve the dimensional stability was using immersion of particle in acidic solution. The objective of this research was to analyse the effect of particle immersing in acetic acid solution at various concentration on physical, mechanical, and durability properties of SPb bonded with isocyanat resin.

\section{Materials and Methods}

\subsection{Materials}

Bamboo belangke and corn stalk were collected from Binjai regency and Medan city, North Sumatra Province. Both materials converted into strand and particle with size as shown in Table 1. Isocyanat resin chose as binder because this adhesive is especialy for exterior application.

TABLE 1: Raw material size.

Particles type
Particles of corn stalk bagasse
Strands of bamboo belangke

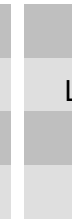

\begin{tabular}{|c|c|c|}
\hline & Size $(\mathbf{c m})$ & \\
\hline Length & Width & Thickness \\
\hline 5 & 2 & 2 \\
\hline 25 & 2.5 & 0.1 \\
\hline
\end{tabular}

\subsection{Methods}

\subsubsection{Particles preparation}

Bamboo strands and corn stalk particles were immersed in acetic acid solution at various concentrations namely $1,3,5$, and $7 \%(v / v)$ for 24 hours. After that, particles were oven dried up to $9 \%$ moisture content. Control or untreated particle $(0 \%)$ also prepared in this research. 


\subsubsection{Board manufacturing}

Producing of SPb similar to com-ply board production. Sandwich particleboard consisted of three layers where is the surface layer (face and back layer) using bamboo strands and core layer using corn stalk particles. The first step, bamboo and corn stalk mixed with adhesive using rotary blending machine. After that, it was inserted into a $25 \mathrm{~cm}$ by $25 \mathrm{~cm}$ mold. Board density and thickness target were set of $0.70 \mathrm{~g} / \mathrm{cm}^{3}$ and $1 \mathrm{~cm}$ respectively. After mat forming, pressing process using hot pressed machine was set on temperature of $160^{\circ} \mathrm{C}$ for 5 minutes, and pressure of $30 \mathrm{~kg} / \mathrm{cm}^{2}$. The final step was conditioning process of sandwich particleboard for 14 days at room temperature.

\section{Results and Discussion}

\subsection{Physical properties}

\subsubsection{Density and moisture content (MC)}

The density value of SPb ranged between of 0.42 to $0.57 \mathrm{~g} / \mathrm{cm}^{3}$ (Fig. 1). The highest and lowest density value resulted by 3 and $0 \%$ acetic acid solution treatment respectively. The density value produced in this study had not met of density target $\left(0.70 \mathrm{~g} / \mathrm{cm}^{3}\right)$. There are two possibilities as caused that, the first is weight loss of particles during the manufacturing process as stated by [4]. Then the second was presence of spring back after conditioning process. The average spring back of SPb in this study was $30 \%$. The board density produced in this research classified into medium density, according to Maloney [5] that medium density particleboards have a density between of 0.4 to 0.8 $\mathrm{g} / \mathrm{cm}^{3}$. All density of board results in this research has met of JIS A 5908 (2003) that requires that value ranged between of 0.40 to $0.90 \mathrm{~g} / \mathrm{cm}^{3}[6]$.

The MC value of SPb ranged between of 7.74 to $10.36 \%$ (Fig. 1). The highest and lowest $\mathrm{MC}$ resulted of treatment in 0 and $5 \%$ acetic acid solution respectively. Trend the data showed that immersing particles in acetic acid solution reduced of MC. It was presumed by replacement of several hydroxyl groups from polymer cell walls with acetyl group bonds. Similar research conducted by [7] who reported that treatment of bamboo particles with acetic acid resulted in a lower board $\mathrm{MC}$ compared to the untreated board. Immersion of particles in acetic acid causes some extractive substances to dissolve and degrade amorphous polysaccharides (hemicellulose) and starch. Decreasing hygroscopic properties causes low water bonding capacity resulting in low moisture 


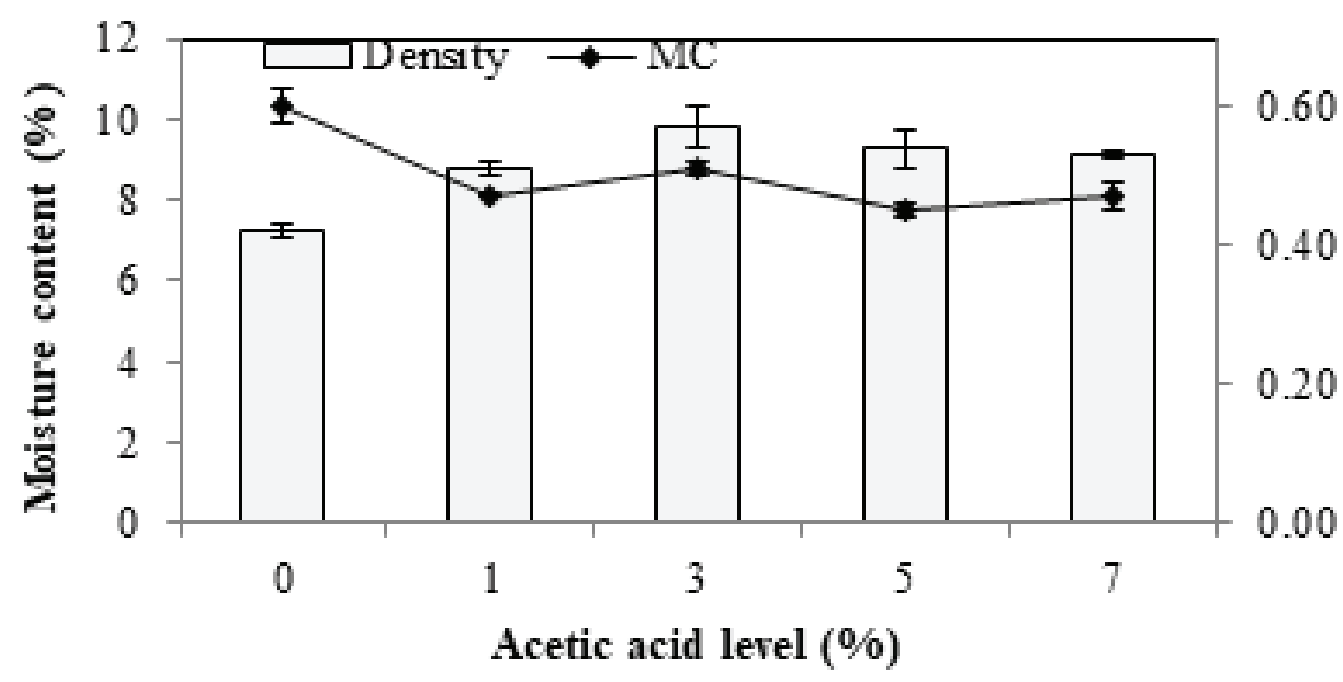

Figure 1: Density and moisture content of sandwich particleboard.

content. Overall the MC of SPb had met JIS A 5908 (2003) that requires a MC value of 5 to $13 \%[6]$.

\subsubsection{Water absorption (WA) and thickness swelling (TS)}

The WA values ranged between of 48.20 to $67.62 \%$ (Fig. 2), the lowest value was obtained from board with immersion in $5 \%$ acetic acid solution and the highest at $0 \%$. The resulting of WA capacity of board was still quite high. According to Rowell [8] acetylated wood can still absorb water through capillary action in cell wall, this is due to the water molecule is smaller than acetyl group, some swelling occurs in acetylated wood but the swelling does not exceed the elastic limits of cell wall. Water absorption value decreases with increasing acetic acid concentration similar to research conducted by [7] who reported that the higher of acid concentration given, the WA of particleboard decrease. Furthermore, [7] stated that several factors causing of lower absorption capacity of particleboard after acid treatment are partial dissolution of extractive substances, degradation of hemicellulose, and a better gluing process.

The TS value of SPb ranged between of 2.70 to $13.96 \%$ (Fig. 1), the lowest value produced from immersion in acetic acid solution of $0 \%$ and the highest at $7 \%$. The trend of the data showed that acetic acid treatment up to $3 \%$ concentration provided a good thickness swelling value. The higher concentration of acetic acid resulted in greater chance of hydrolysis. According to Harmsen et al. [9], chemical modification treatment using weak acids will cause hemicellulose hydrolysis that has an impact on increasing porosity. Based on JIS A 5908 (2003), TS value of SPb as a whole almost met the JIS 

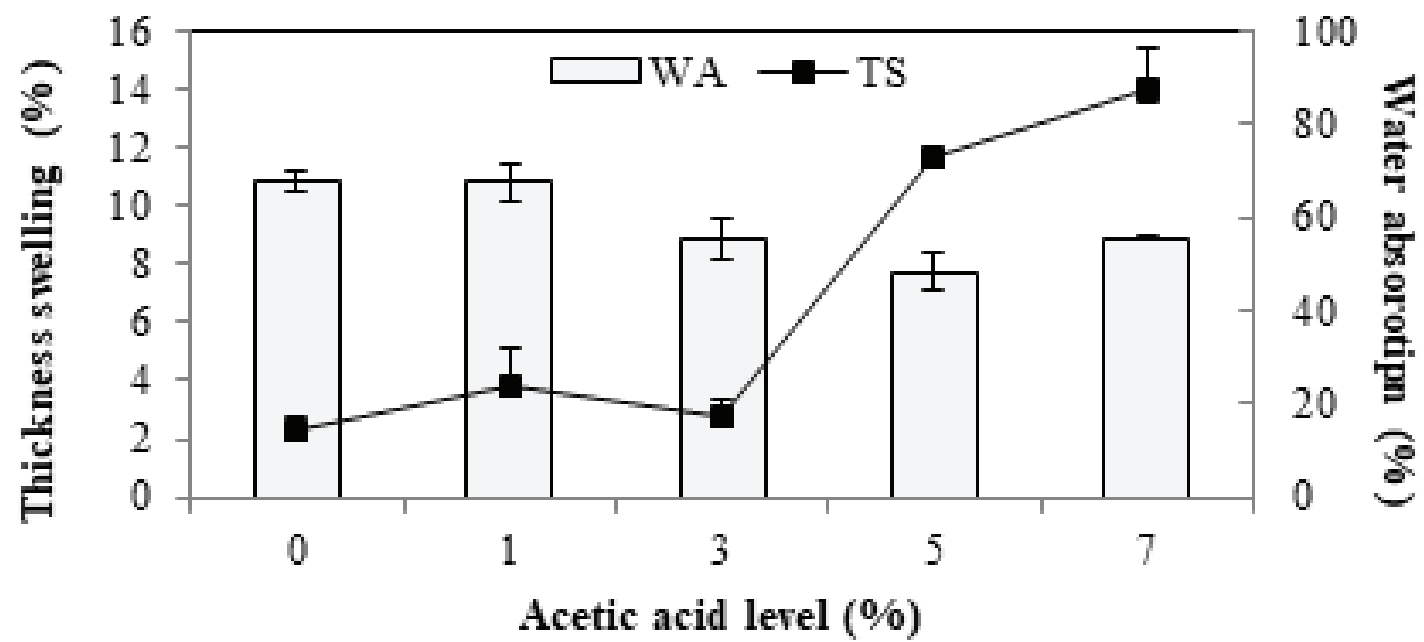

100

80

2

Acetic acid level (\%)

Figure 2: Water absorption and thickness swelling of sandwich particleboard.

A 5908 (2003) that requires a maximum value of $12 \%$ [6], except of $7 \%$ concentration treatment. 


\subsection{Mechanical properties}

\subsubsection{Modulus of elasticity (MoE) and modulus of rupture (MoR)}

Modulus of elasticity value of SPb ranged between of $14,756.73$ to $40,316.26 \mathrm{~kg} / \mathrm{cm}^{2}$ (Fig. 3). The highest and lowest MoE value resulted by board with treatment in a $3 \%$ and $0 \%$ respectively. The data trend showed that optimum of MoE value was obtained on board with treatment in a 3\% acetic acid solution, above this concentration showed a decrease of MoE value, this similar to result who was conducted by [10]. Some previous studies also show that acetylation treatment can reduce MOE and MOR values [11-14]. Overall the MoE value of SPb product had met JIS A 5908 (2003) that requires a minimum MoE value of $20,000 \mathrm{~kg} / \mathrm{cm}^{2}$ except the control board [6].

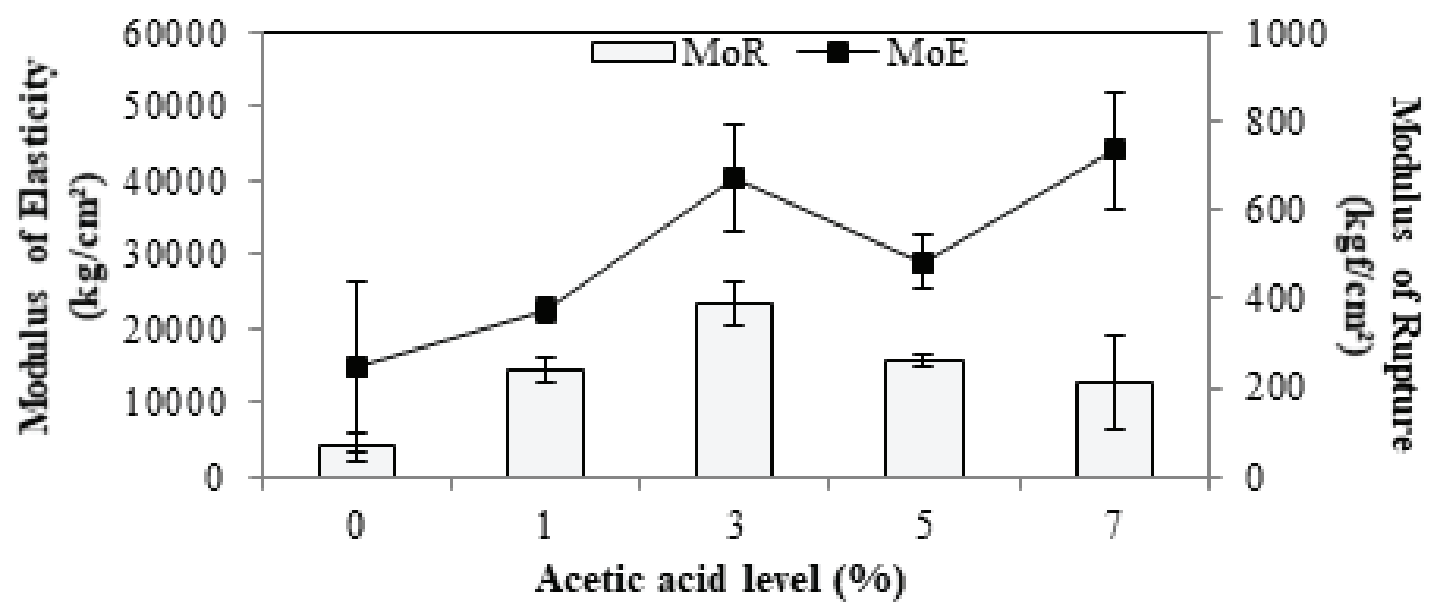

Figure 3: Modulus of elasticity and modulus of rupture of sandwich particleboard.

Modulus of rupture value of SPb ranged between of 67.05 to $389.03 \mathrm{~kg} / \mathrm{cm}^{2}$ (Fig. 3). The highest MoR value of board with treatment in 3\% acetic acid solution and the lowest at concentration of $0 \%$. The trend of the data for MoR was similar to the MoE value. The MoR value increases up to 3\% concentration and decreases at higher concentrations. Acetylization can reduce of MoE and MoR values when acetic acid concentration have exceeded their optimum levels. Overall MoR value of SPb had met JIS A 5908 (2003) that requires a minimum MoR value of $82 \mathrm{~kg} / \mathrm{cm}^{2}$ except for the control board [6].

\subsubsection{Internal bond (IB)}

The internal bond value ranged between of 0.29 to $1.04 \mathrm{~kg} / \mathrm{cm}^{2}$ (Fig. 4). The highest and lowest IB value produced by board with immersion in $1 \%$ and $0 \%$ acetic acid solution respectively. Overall the IB value in this study did not met of JIS A 5908 (2003), it was 
due to the presence of bark of corn stalk particles. Similar results were also shown by $[15,16]$ who reported that a low IB value of particleboard made from sorghum stalk was due to by presence of sorghum stalk bark. The bark had more slippery and hydrophobic character so it will be a barrier to the gluing process.

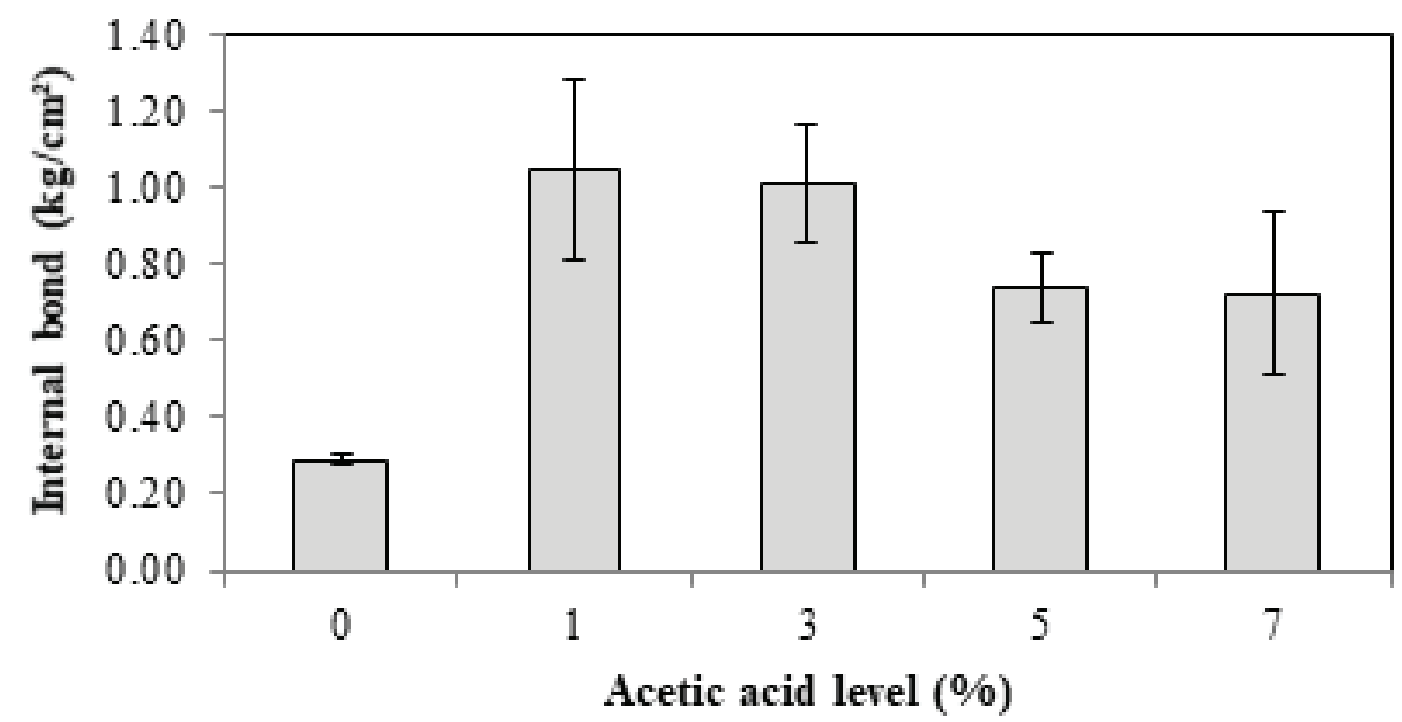

Figure 4: Internal bond of sandwich particleboard.

Based on Fig. 4, there was a tendency to increase of IB value due to the treatment in acetic acid solution compared to the untreated, but the trend of IB decreased with higher concentration of acetic acid. It was due to by two things namely extractive and particles acidity. Immersion treatment in acetic acid solution can dissolve extractive substances so that the gluing process will take place properly. Furthermore, the higher acetic acid concentration causes an increase in particles acidity. Although isocyanate adhesives are acid-tolerant adhesives, there are limits to the conditions in which strong acids cause these adhesives cannot work optimally. As reported by [17] that value of internal bonding constancy of flakeboard made of limestone wood does not meet ANSI standards, this is due to the wood has strong acidity. Overall IB value of sandwich particleboard produced did not met JIS A 5908 (2003) that requires a minimum IB value of $1.50 \mathrm{~kg} / \mathrm{cm}^{2}[6]$.

\subsection{Durability properties}

\subsubsection{Weight loss}

Weight loss of board ranged from 2.45 to $6.07 \%$ (Fig. 5) where the highest and lowest of weight loss were produced by immersion treatment in $0 \%$ and $3 \%$ acetic acid solution 
respectively. According to SNI 01-7207-2006, immersion treatment in acetic acid solution exceeded of $1 \%$ concentration was classified into resistant (class II), while of control board and immersion in $1 \%$ acetic acid solution were classified into medium category (Class III) [18].

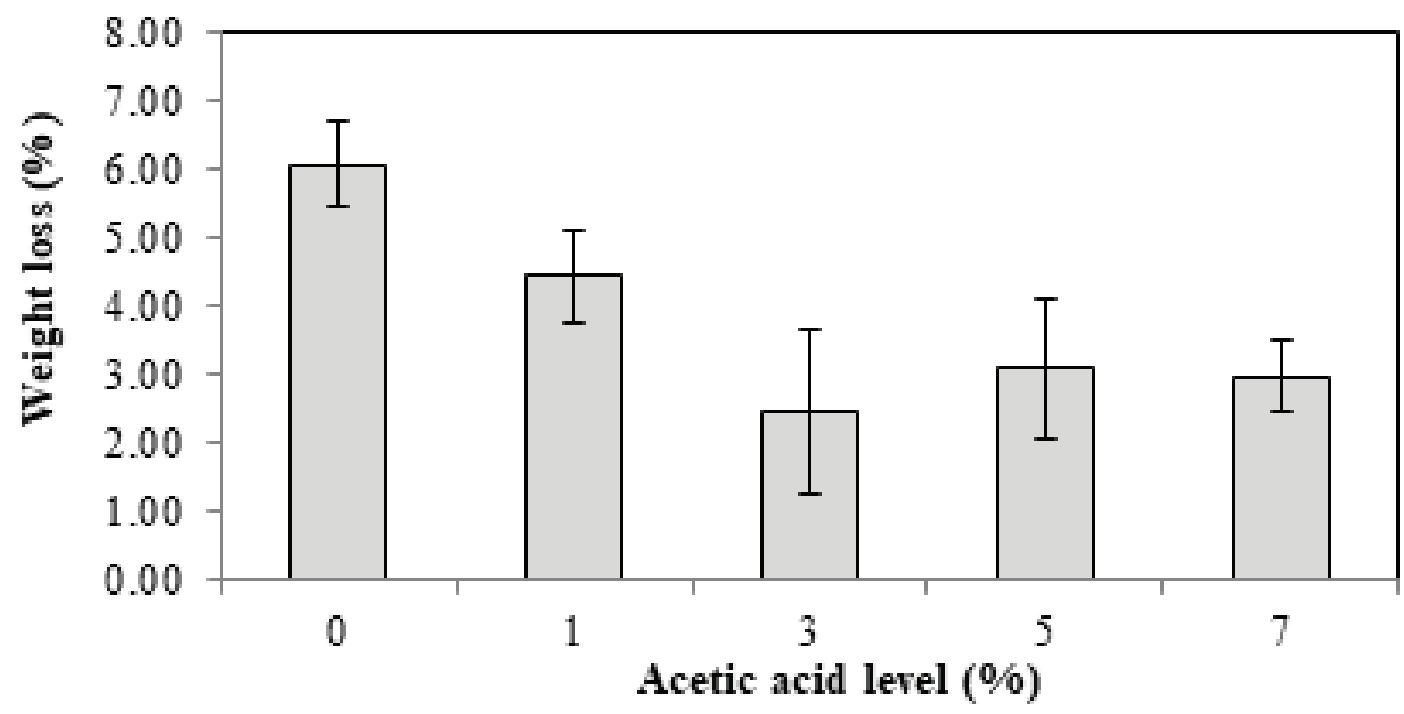

Figure 5: Weight loss of sandwich particleboard.

The highest weight loss of control board was due to the amount of starch contained in corn stalks and bamboo, which it was favorites feed for wood-destroying organisms. As reported by [19] that the high starch content of bamboo is more susceptible to attack of wood destroying organism especially of termites and powder post beetle. The tendency to decrease the weight loss of board with the immersion treatment in acetic acid due to immersion in acetic acid degrades starch and causes some extractive substances to dissolve [7]

\section{Conclusions}

Based on thickness swelling and strength properties results, particle treatment in $3 \%$ acetic acid concentration resulted the best quality of board. Almost all testing of density, moisture content, thickness swelling, MoE, and MoR fulfilled JIS A5908 (2003) except of IB value. Durability test showed that weigh loss of SPb in this research ranged of 2.45 to $6.07 \%$. It was classified into moderate to durable class. 


\section{Acknowledgement}

We would like to express my sincerely thanks to Universitas Sumatera Utara for supporting research fund through to "Talenta Research Grant" No: 5388/UN5.1.R/PPM/2017 Date of May 22, 2017.

\section{References}

[1] Mohmod A.L. et al. (1990). Anatomical features and mechanical properties of three malaysian bamboos, J. Tropical Forest Science. 2(3), 227-234.

[2] Papadopoulos A.N. et al. (2004). Bamboo chips (Bambusa vulgaris) as an alternative lignocellulosic raw material for particleboard manufacture, J. Holz Roh Werkst. 62, 36-39.

[3] Kasim J. et al. (2001). Properties of particleboard manufactured from commonly utilized malaysian bamboo (Gigantochloa scortechinii), Pertanika J. Trap. Agric. Sci. 24(2), 151-157.

[4] Buffalino L. et al. (2012). Particleboard made from australian red cedar: processing variables and evaluation of mixed species, Journal of Tropical Forest Science. 24(2), 162-172.

[5] Maloney, T.M. (1993). Modern Particleboard and Dry Process Fiberboard Manufacturing, Miller Freeman Publications, San Fransisco.

[6] [JSA] Japanese Standard Association. (2003). Japanese Industrial Standard Particleboard, JIS A 5908, Japanese Standard Association, Jepang.

[7] Febrianto F. et al. (2016). Physical and mechanical properties of particle board of betung bamboo with acetic acid soaking treatment, J. IImu Teknologi Kayu Tropis. 14(1), 23-38.

[8] Rowell, R.M. (2007). Chemical Modification of Wood. Handbook of Engineering Biopolymers Homopolymers, Blends and Composites, Carl Hanser Verlag, Munich.

[9] Harmsen, P.F.H., Huijgen, W.J.J., Lopez, L.M.B., and Bakker, R.R.C. (2010). Literature Review of Physical and Chemical Pretreatment Processes for Lignocellulosic Biomass, Project Report, Wageningen, Germany.

[10] Iswanto A.H. et al. (2018). The effect of particle immersing in acetic acid solution on dimensional stability and strength properties of particleboard, IOP Conf. Series: Earth and Environmental Science. 126, 012017 [doi: 10.1088/1755-1315/126/1/012017]

[11] Larsson P. et al. (1994). A study of the strength, hardness and deformation of acetylated scandinavian softwoods, Holz Roh Werkstoff. 52(2), 83-86. 
[12] Militz H. (1991). The improvement of dimensional stability and durability of wood through treatment with noncatalysed acetic acid anhydride, Holz Roh Werkstoff. 49(4), 147-152.

[13] Bongers H.P.M. et al. (2003). Mechanical properties of acetylated solid wood treated on pilot plant scale, In Van Acker J, Hill CAS, Ed., Proceeding of the First European Conference on Wood Modification, pp. 341-351.

[14] Jorissen A. Et al. (2005). The influence of acetylation of radiata pine in structural sizes on its strength properties. Wood Modification: Processes, Properties and Commercialisation, In Militz H, Hill C, Ed., Proceedings of the Second European Conference on Wood Modification, pp. 108-115.

[15] Iswanto A.H. et al. (2014). Effect of resin type, pressing temperature and time on particleboard properties made from sorghum bagasse, Agriculture, Forestry and Fisheris. 3(2), 62-66.

[16] Iswanto, A.H. et al. (2017). The physical, mechanical and durability properties of sorghum bagasse particleboard by layering surface treatment, J. Indian Acid Wood Sci. 14(1), 1-8.

[17] Kwon J.H. (2007). Effects of species on the isocyanate-bonded flakeboard properties, Mokchae Konghak. 35(5), 38-45.

[18] [BSN] Badan Standarisasi Nasional. (2006). SNI Mutu Papan Partikel SNI 01-72072006, Badan Standarisasi Nasional, Jakarta

[19] Febrianto F. et al. (2014). Natural durability of five bamboo species against termites and powder post beetle, J. IImu Teknologi Kayu Tropis. 12(2), 146-156. 